\title{
DE LA FILMOGRAFIE LA EDUCAȚIE ȘI CUNOASTTERE: ETAPELE DESCOPERIRII SINELUI ÎN ECRANIZAREA MICUL PRINT (DUPĂ ANTOINE DE SAINT-EXUPÉRY)
}

\author{
Emanuela-Liliana Bandici*
}

Abstract: In this study attempt to present the stages of growth from the perspective of the relationship between children and adults. At the same time I want to illustrate the stages of self discovery in the show The Little Prince by Antoine de Saint Exupery. Childhood friendship modern world, secular, selfdiscovery, death and rebirth in another dimension are deep challenges of all times past or present.

Keywords: Childhood, friendship, modern world, relationship, The Little Prince, Antoine de Saint Exupery.

\section{Prolegomena}

Micul Prinț al lui Antoine de Saint-Exupéry va fi mereu în ,atenție" prin problematica sa actuală, de-a dreptul clasică ${ }^{1}$.

Copilăria, prietenia, lumea modernă, secularizată, descoperirea sinelui, moartea și renașterea într-o altă dimensiune sunt adânci provocări ale tuturor vremurilor trecute sau actuale.

Firul narativ debutează simplu, surprinzând imaginea unei mame moderne, al cărei unic obiectiv de viață este educaţia propriei fetițe sau mai ales devenirea ei. Lucrurile se complică atunci când fetiţa se întâlnește printr-o fericită, neașteptată, binecuvântată întâmplare cu un bătrânel care trăia alături.

\footnotetext{
*Teacher, „Mihai Eminescu” Secondary School, Alba Iulia, România.

${ }^{1}$ regia: Mark Osborne; scenariul: Irena Brignull şi Bob Persichetti, după romanul omonim de Antoine de Saint-Exupéry; produs de: Dimitri Rassam, Aton Soumache şi Alexis Vonarb; Antoine de Saint-Exupéry, Micul Prinţ, Bucureşti, Edit. Rao, 2011, p. 13.
} 
Tehnica narativă a povestirii în ramă permite evoluția a două perspective diferite de educație pe care fetița le va primi independent de propria voință.

Educația este, deci, o problemă actuală a societății în care trăim. Omul modern, desprins cu desăvârșire de adevărata lui natură aleargă spre idealuri mărețe.

\section{Hermeneutica unei deveniri}

Copilul primește cu rigoare seturi de norme și reguli pe care trebuie să și le assume, fie că vrea, fie că nu vrea. Acesta devine un mic pion disciplinat în marele puzzle al lumii acesteia, sau ... un număr. Atunci când se afla la interviul pentru a fi admisă la Academia Werth, ea este un număr „017”, un roboțel care-și repetă cu disperare răspunsul la marea întrebare: „Da, eu merit. Trei lucruri mă fac să-mi doresc să intru la Academia Werth: inteligentă, serioasă, fermă”, chiar dacă fusese întrebată ce vrea să se facă atunci când va fi mare.

Tot o formă de educație este și aceea că nereușita are întotdeauna un plan B, care este „noul plan” A. În vederea reușitei viitoare, mama se mută împreună cu fiica ei mai aproape de academie, ea subliniază că $i-a$ făcut viitorul posibil și îi prezintă fetiței planul vieții sale: „Vei folosi fiecare minut, oră și zi conform planului”, „Vei fi singură acolo”. „Nu ne permitem să pierdem nicio secundă". În felul acesta, mama o asigura că va fi un adult minunat (,a wonderful grown-up") ${ }^{2}$.

Constatând că fetița nu-i respectă decizia, că nu s-a achitat de responsabilitățile de studiu individual zilnic, mama izbucnește în spiritul adulților. Conversația ajunsă la cote alarmante ale conflictului pune în lumină un adevăr zdrobitor: copilul e un univers nou, unic, are gânduri, vise, aspirații independente de ale părinților lui.

${ }^{2}$ Ibidem. 
În goana după „frumosul lui a avea”, copilul s-a transformat într-un bun prețios, fără decizii, fără suflet, fără sentimente și fără opinii: „-Ai reușit să-ți minți planul vieții! / -Aia? E doar o tablă plină de magneți! / Îți pasă mai mult de tablă decât de mine! / -Te înșeli. Îmi pasă la fel de mult de tablă ca de tine! Tu ești tabla! / E viața ta şi eu îmi asum fiecare responsabilitate! / -E versiunea ta a vieții mele, nu a mea!"

Apoi, o altă replică dureroasă străpunge sufletul mamei: „Dacă ai fi prin jur, ai vedea asta."; subliniind din nou o realitate tristă a vremurilor în care trăim: părintele e mult prea ocupat cu el însuși, cu devenirea sa, cu dezvoltarea sa personală, iar copilul devine un mic cerșetor de ,iubire” și de „prezență”. „-Știi foarte bine de ce lucrez așa mult. / -Ești exact ca $E l$ acum. Prea ocupată, mereu lucrând. Cât mai durează până dispari și tu?"

„El” din dialogul de mai sus e tatăl, prezent în film doar prin cadourile anuale de ziua fetiței, niște globuri de sticlă care prefigurează imaginea bunăstării: metropole în capsulă, „visuri îngropate în eprubetă".

O oarecare concluzie se impune: o nevoie universal valabilă a copiilor este aceea de siguranță, de protecție. Tot mai mulți dintre aceștia își pun fireasca întrebare pe care fetița a adresat-o mamei mai sus: „Oare când voi fi din nou părăsit?", iar teama aceasta nerezolvată în copilărie va fi o problemă de adult însingurat și fără direcție.

Întâlnirea cu bătrânelul rătăcit de peste timpuri într-o lume secularizată reprezintă pentru fetiță o nouă și inedită formă de educație, o primă treaptă a cunoașterii spre descoperirea propriei identităţi.

Fetița își petrece ziua singură, după regulă, își face lecțiile, face sport, vorbește îngrijit, se poartă disciplinat și riguros. Ea face cunoștință cu fostul aviator (ajuns la o vârstă înaintată) în mod intempestiv. În încercările acestuia de a-și porni avionul, peretele casei unde locuia fetița este perforat de elicea desprinsă de aparat, iar spărtura din zidul care-i despărțea devine o poartă de trecere într-un univers magic, miraculous. Spargerea zidului înseamnă evadarea din 
spațiul strâmt al dependenței și al tutelei materne, ieșirea din enclavă. Perforarea dinspre exterior a „găoacei” îi dă fetei șansa, forța și voința de a primi aripi, aripi spre cunoaștere și descoperire.

Totul e nou și altfel. De aici începe aventura, descoperirea, autocunoașterea. Casa bătrânului e un sanctuar în care nu se păstrează, ci se reiterează o lume, se naște un univers sacru, în care toate lucrurile au povestea lor, o bucurie intrinsecă, un parfum ce vine dintotdeauna pentru totdeauna.

Întâlnindu-l pe bătrân, ea întâlnește de fapt vocea lui Dumnezeu, vocea creatorului. Bătrânul este simbolul duhovnicului, al iniţierii, el îi deschide ochii sufletului, cei cu care poți vedea cu adevărat. Fetița devine astfel un ucenic al înțelepciunii și merge cu credință pe drumul acesta. Tot alături de el descoperă lumea care începe din curte - un alt univers, unul vesel, colorat, o copie a raiului în miniatură, strecurat în griul cotidian al secolului XXI, cu el simte prospețimea florilor, se bucură de libertatea zmeielor.

Treptele cunoașterii ${ }^{3}$ se urcă încet și anevoios precum în copacul unde se află agățat zmeul.

Cunoașterea și părtășia la povestea de viață a Micului Prinț o face să-i crească aripi pe interior și să conștientizeze că, atunci când misterul e prea puternic, nu îndrăznești să i te opui.

Fetița intră în lumea Micului Prinț, găsind o părticică din povestea acestuia pe un avion de hârtie, între monedele primite de la aviator. Tot aici găsește în miniatură micuța planetă verde, trandafirul, avionul, săbiuța, chiar și figurina micuțului.

Odată intrată în poveste, ea începe un drum inițiatic, al maturizării, al cunoașterii, al eliberării, al bucuriei și tristeții deopotrivă, dar mai ales al speranței. E un drum pe care cei doi îl petrec la început în universuri paralele. Fiecare pe planeta și în lumea sa, fiecare e unic, special în felul său, prototipul omului ideal de la începutul vieții sau mai bine zis de dinainte de cădere.

În inocența sa primară, Micul Prinț își dorește o oaie nici prea

${ }^{3}$ Duane, Elgin, Voluntary Simplicity. Toward a way of life that is outwardly simply, inwardly rich Londra, Harper, 1981. 
bolnavă, nici prea bătrână, mai ales una care să trăiască veșnic, una care 1-ar putea însoți într-o călătorie fără sfârșit, o oaie simbol al curăției, al ascultării și al răbdării, al jertfei.

Când aviatorul îi desenează o cutiuță cu câteva ochiuri deschise spre înafară, micuțul constată cu bucurie că este exact ce-și dorește. Acolo - in utero - la adăpostul căldurii materne originare, e universul sacru dinainte de începuturi. Aceasta-i amintește de micuța lui planetă, de $\operatorname{Rose}^{4}$ de a cărei iubire fugise, împins de o temere inexplicabilă.

Părăsirea asteroidului B-612 trimite la desprinderea omului din Rai. Călătoria e lină, calmă, senină, pe aripi de pasăre, având ca destinație finală planeta Pământ.

„Drumul” până aici prefigurează tipologii umane ce-i vor fi puse înainte în devenirea sa ca adult.

Pe asteroidul său, Regele este prototipul trufiei, al slavei deșarte. El se laudă că i se închină lumea și că totul îi este lui posibil, dar nu e capabil să-i redea asfințitul mult râvnit pe care-l trăise în trecut.

Vanitatea își găsește expresia pe planeta și în persoana Omului Încrezut, care-și pleacă pălăria pentru că este admirat și cere asta.

Poate cel mai bine conturat și actual profil este cel al Omului de Afaceri, subliniindu-se că în lumea asta totul poate fi numărat, contorizat, cumpărat, luat în posesie.

Ajuns la destinație, întâlnește Șarpele, simbol al ispitei, al înșelăciunii și meschinăriei acestei lumi, care-i propune să-1 ajute să se întoarcă pe planeta sa în schimbul „umbrei”, îmblânzește vulpea, care-i devine părtaș în cele ale înțelepciunii.

Ce-1 face unic pe Micul Prinț este tocmai puritatea, profunzimea gândirii, clarviziunea. Odată ajuns pe Pământ, el conștientizează că singurul loc care-1 face fericit cu adevărat este întoarcerea la „Raiul” din care fugise din teamă, din curiozitate sau, mai degrabă, din lipsa de conștientizare valorică.

Totul se raportează la mica floare plină de iubire care, cu

${ }^{4}$ În limba franceză trandafirul = la rose (subst. fem.) 
siguranță, îl va fi așteptând: ,-Stelele sunt mai frumoase datorită unei flori ce nu poate fi văzută”.

Probabil cea mai însemnată etapă a descoperirii sinelui este felul vizionar, senin, detașat în care Micul Prinț vede moartea: „Întruna din aceste stele am să locuiesc eu. Într-una din ele am să râd și când te vei uita pe cer noaptea, e ca și cum toate stelele ar râde".

Înțelepciunea acestuia merge până acolo încât înțelege imposibilitatea întoarcerii la origine în trup: „Voi fi ca o carcasă abandonată. Nu-i nimic trist în legătură cu carcasele vechi."

Viața însă trebuie și merită a fi trăită frumos. Bucuria acesteia nu constă în cantitate, ci în capacitatea de a te putea bucura, de a trăi prezentul lui ,a fi”, de a vedea frumusețea în sine: „Doar cu inima poți vedea cu adevărat. Ce-i esențial e invizibil ochiului."

Deși se simte trădat când întâlnește o grădină întreagă de trandafiri, personajul realizează repede, cu înțelepciunea unui duhovnic albit de vreme și de har că: „Omul crește mii de trandafiri acolo unde locuiește și nu găsește ceea ce caută. Ceea ce caută ei poate fi găsit într-un singur trandafir sau în puțină apă."

\section{În loc de concluzii}

Ajunsă la finalul poveștii, fetița nu se resemnează cu idea nefericită a întoarcerii pe planetă a Micului Prinț, care se traduce prin moarte, pe care aceasta, inițiată la Școala „bătrânului dascăl” o vede cu ochii sufletului, o înțelege, o simte. Ea pleacă în căutarea Micului Prinț, intr-o călătorie a minții și a sufletului. Pilotarea avionului în tovărășia vulpii reprezintă o nouă evadare, luarea vieții în propriile mâini, preîntâmpinarea destinului. Îl regăsește pe Micul Prinţ în pielea unui adult neîmplinit, nefericit, pradă UITĂRII, care-i întunecase sufletul și-1 rătăcise cu desăvârșire. În mod eroic, fetița îl smulge din ghearele uitării și ale singurătății și-l readuce acasă.

Întâlnirea cu trandafirul care se ofilise de tristețe, nefericire îi provoacă acestuia o durere profundă, însă iubirea și credinţa produc minuni. Floarea se transformă într-un univers paralizant de frumos, iar Domnul Prinț parcurge într-o clipită traseul dinspre adult spre 
copilul innocent și rar de altădată. ,-Pot să văd. N-a fost un trandafir comun. A fost unică în tot universul. Imi amintesc de ea. Îmi amintesc totul. Nu-i plecată. E tot aici”, căci cu sufletul poți vedea cu adevărat. $\mathrm{Cu}$ aceeași ochi ai iubirii, mama fetiței acceptă

\section{References}

1. Duane, Elgin, Voluntary Simplicity. Toward a way of life that is outwardly simply, inwardly rich Londra, Harper, 1981.

2. Boisvert, Dominique, ABC-ul Simplității Voluntare, Éditions Écosociété, 2005.

3. Ariès, Paul, La Simplicité Volontaire contre le mythe de l'abondance, Paris, La Decouverte, 2010.

4. Duane, Elgin \& Mitchell, Arnold, Voluntary Simplicity, The Coevolution Quarterly, 1977.

5. Antoine de Saint-Exupéry, Micul Prinţ, Bucureşti, Edit. Rao, 2011 